\title{
UNILATERAL HYPERTHERMIC SHOCKS TO RAT TESTIS
}

\author{
S. R. BAWA, KULDIP G. KANWAR AND PAWAN K. SINGAL
}

\author{
Department of Biophysics, Panjab University, Chandigarh, India
}

(Received 31st August 1970, revised 22nd December 1970)

It is well known that rigs or cryptorchids with abdominal testes are sterile (Crewe, 1922; Nordby, 1928). Further, in unilateral cryptorchidism, clinical as well as experimental, normal functioning of the abdominal testis is impaired; the nature of the damage is similar to that described for the bilaterally cryptorchid testis (see Kormano, Härkönen \& Kontinen, 1964).

Though testicular histology in response to hyperthermia has recently been investigated, biochemical, histochemical and cytochemical studies on the mammalian testis subjected to hyperthermia are few (see Collins \& Lacy, 1969). No attempt has yet been made to study both testes from the same animal, where one is maintained at normal temperature and the other testis is subjected to heat. Comparative studies on normal and heat-treated testes from the same animal would supply direct information on whether the effects produced are local or whether some form of hormonal mechanism is involved in the impairment of spermatogenesis. Such information is a prerequisite before hyperthermia can be safely recommended as an effective agent for inducing male sterility.

In the present studies, forty sexually mature, male, albino rats, each weighing 200 to $250 \mathrm{~g}$, were used. After anaesthetizing with Nembutal $(5 \mathrm{mg} / 100 \mathrm{~g}$ body weight), the two testes were pressed apart with a wooden rod and the left side of the scrotum of each animal was immersed in a water-bath maintained at $43.5^{\circ} \mathrm{C}$ for $75 \mathrm{~min}$, in five steps, each of $15 \mathrm{~min}$ duration. In order to counteract the possible dissipation of heat from the left testis, the right was kept cold by covering it repeatedly with cotton swabs immersed in cold water. These rats were killed after 21 days and their testes were removed, weighed and processed separately.

Quantitative estimation of cholesterol was made according to the Liebermann-Burchard method (see Oser, 1965). The estimation of alkaline and acid phosphatases involved the use of the incubating media of Bodansky (1933) and of Shinowara, Jones \& Reinhart (1942), respectively, and for the subsequent determination of inorganic phosphorus, the method of Fiske \& SubbaRow (1925) was used. For histochemical analyses of alkaline and acid phosphatases, the tissue was fixed in $10 \%$ formalin at $4^{\circ} \mathrm{C}$ and further treated according to Gomori (1964).

A significant decrease $(P<0.01)$ in the weight of the heat-treated testis in all the animals was observed (Table 1). There was no effect on the germinal 
epithelium of the untreated testis which exhibited normal spermatogenic activity (Pl. 1, Fig. 1). By contrast, the germinal epithelium was adversely affected in the heated testis (PI. 1, Figs 2 to 5). Spermatogenesis was drastically impaired, the spermatogonia and the Sertoli cells being the most heat resistant (Pl. 1, Fig. 3). The tubules in general were heavily vacuolated (Pl. 1, Figs 3, 5) and severely damaged, so much so that some of them were virtually empty, containing only a few spermatogonia and Sertoli cells (Pl. 1, Fig. 3).

In the treated testis, due to the degeneration of the germ cells, the seminiferous tubules appeared shrunken and the basement membrane assumed a collapsed and wavy appearance (Pl. 1, Fig. 2). In some of the tubules, the basement membrane was detached from the germinal epithelium (Pl. 1, Fig. 4) and appeared markedly thickened with an increased affinity for PAS (Pl. 1, Fig. 5). A parallel histochemical increase in the alkaline phosphatase of the basement membrane, as shown by Gomari's technique, was also noted (Pl. I, Fig. 2). Both in the treated and control testes, however, there was no histochemically demonstrable acid phosphatase activity, even after repeated trials.

TABLE 1

EFFECT OF HEAT ON RAT TESTES

\begin{tabular}{l|c|c|c}
\hline \multicolumn{1}{c|}{ Particulars } & Heated testis & Control testis & $\begin{array}{c}\text { Statistical } \\
\text { significance } \\
(\mathrm{P})\end{array}$ \\
\hline Weight of testis (mg/100 g body weight) & $250 \pm 19(36)^{*}$ & $600 \pm 23(36)$ & $<0.01$ \\
Cholesterol (mg/g tissue weight) & $6 \cdot 23 \pm 0 \cdot 11(17)$ & $2 \cdot 45 \pm 0 \cdot 8(17)$ & $<0.01$ \\
Alkaline phosphatase/g tissue weight & $2028 \pm 217 \mathrm{U}(9)$ & $1084 \pm 203 \mathrm{U}(9)$ & $<0.01$ \\
Acid phosphatase/g tissue weight & $961 \pm 337 \mathrm{U}(8)$ & $431 \pm 219 \mathrm{U}(8)$ & $>0.05$ \\
\hline
\end{tabular}

* Figures in parentheses show the number of samples analysed.

$\mathrm{U}$ is the unit of enzyme activity and is defined as the amount of inorganic phosphate in $\mu \mathrm{g}$ liberated by $1 \mathrm{~g}$ of tissue in $1 \mathrm{hr}$ at $37^{\circ} \mathrm{C}$.

The structural and chemical changes in this membrane are highly suggestive of any alteration or disturbance to the physiology of the treated testis.

In the heated testis, no interstitial cell hyperplasia was observed as compared with the control testis though increased alkaline phosphatase activity was observed in the Leydig cells and the walls of the blood capillaries (PI. 1, Fig. 2).

\section{EXPLANATION OF PLATE 1}

Fig. 1. Untreated testis. Seminiferous tubule showing uninterrupted spermatogenesis. Zenker/Delafield haematoxylin-eosin. $\times 266$.

Frg. 2. Heat-treated testis. Heavily damaged seminiferous tubules showing thickened basement membranes with intense alkaline phosphatase activity. Cold $10 \%$ formalin/ Gomori. $\times 266$.

Fig. 3. Heat-treated testis. Seminiferous tubule containing only spermatogonia and Sertoli cells. Zenker/Delafield haematoxylin-eosin. $\times 266$.

Frg. 4. Heat-treated testis. The seminiferous tubule shows detachment of the basement membrane and disorganization of the germinal cells. Zenker/Delafield haematoxylineosin. $\times 266$.

Fig. 5. Heat-treated testis. Heavily vacuolated seminiferous tubule showing marked thickening of the basement membrane. Zenker/PAS-Delafield haematoxylin. $\times 266$. 
PLATE 1
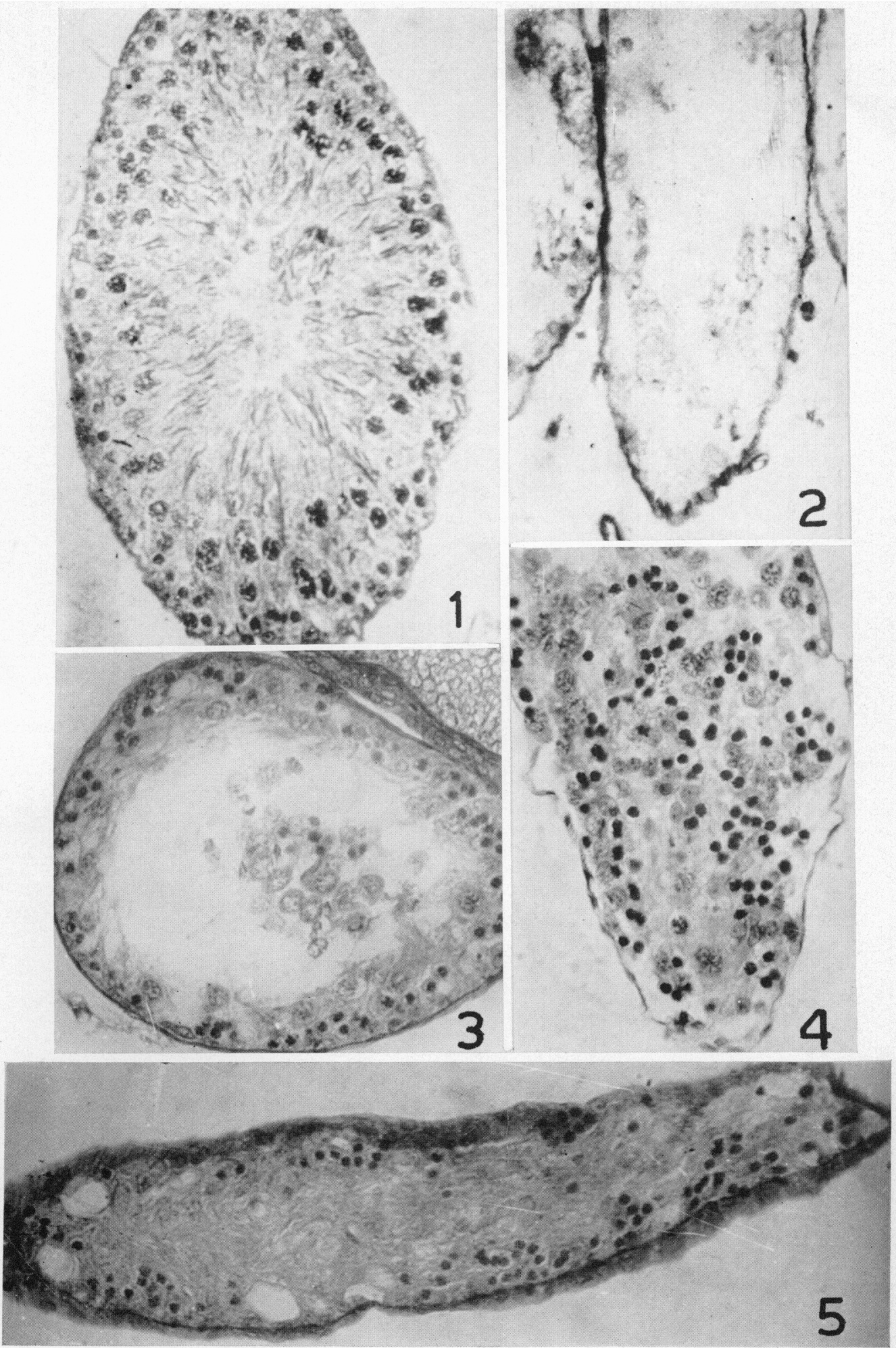
The increase in the alkaline phosphatase in the basement membrane and the interstitium of the experimental testis was substantiated by the biochemical data. These revealed a significant increase $(P<0.01)$ in the content of alkaline phosphatase (Table 1).

In the control testis, acid phosphatase was localized in the seminiferous epithelium, mainly in the nuclei of spermatogonia and spermatocytes. Quantitatively, this enzyme showed an insignificant decrease $(P>0.05)$ in the heattreated testis (Table 1) but there was a distinct histochemical shift of the enzyme's activity; in the heat-treated testis, there was enhanced enzyme activity in the interstitium but a decline in the seminiferous tubules.

In the heat-treated testis, the Sertoli cells in particular showed a marked increase in their lipid content compared to similar cells in the control testis from the same animal. Total cholesterol/g tissue weight also showed a significant $(P<0.01)$ increase in the treated testis compared with the untreated one (Table 1). Increase and decrease of testicular cholesterol has been considered physiologically important since it is implicated in the inhibition/stimulation of sperm-formation in the testes (Lacy, 1967).

The present studies suggest that the impairment of spermatogenesis in the heat-treated testis may be due to the involvement of certain local factor(s) rather than of some general hormonal mechanism inasmuch as the effects of heat were restricted to the treated testis while the untreated one continued to function normally.

We believe that the normal activity of the seminiferous tubules is brought about by a factor or factors intermediary between the pituitary-adrenal hormones, known to affect the gonads, on the one hand, and those responsible for stimulating sperm-formation in the seminiferous tubules on the other. As Lacy (1967) suggested, the probable site for such a factor seems to reside in the seminiferous tubule itself since the interstitium is hardly damaged even after repeated hyperthermic shocks. Lacy (1967) postulated that 'Sertoli cell hormone' is responsible for inhibiting sperm formation. Further work is needed, however, before any enzymatic involvement can be excluded.

\section{REFERENCES}

Bodansky, A. (1933) Phosphatase studies. ii. Determination of serum phosphatase. Factors influencing the accuracy of the determination. $\mathcal{F}$. biol. Chem. 101, 93.

Collins, P. \& LAcY, D. (1969) Studies on the structure and function of mammalian testis. ii. Cytological and histochemical observations on the rat after a single exposure to heat applied for different length of time. Proc. R. Soc. B, 172, 17.

Crew, F. A. E. (1922) A histological study of the undescended testicle of the horse. F. comp. Path. Ther. $35,62$.

Fiske, G. H. \& SubbaRow, Y. (1925) The colorimeteric determination of phosphorus. F. biol. Chem. 66,375 .

GomoRI, G. (1964) Microscopic histochemistry principles and practice. University of Chicago Press.

Kormano, M., Härkönen, M. \& Kontinen, E. (1964) Effect of experimental cryptorchidism on the histochemically demonstrable dehydrogenases of the rat testis. Endocrinology, 74, 44.

LACY, D. (1967) The seminiferous tubule in mammals. Endeavour, 26, 101.

NoRdBy, J. E. (1928) Spermatogonium and spermatocyte degeneration in cryptorchid testis of the horse. Trans. Am. microsc. Soc. 47, 54.

Oser, B. L. (1965) Hawk's physiological chemistry, 14th edn, p. 246. McGraw-Hill, New York.

Shinowara, G. Y., Jones, L. M. \& ReInharT, H. L. (1942) The estimation of serum inorganic phosphate and "Acid" and "Alkaline" phosphatase activity. F. biol. Chem. 142, 921. 